\title{
Diversity of Woody Plant Species of Gamuwa and Oda Forests of Humbo Carbon Project, Wolaita, Ethiopia: For Conservation and Management of Forests
}

\author{
Markos Kuma \\ Department of Biology, Wolaita Sodo University, Wolaita Sodo, Ethiopia \\ Correspondence should be addressed to Markos Kuma; kuma.markos03@gmail.com
}

Received 7 June 2016; Accepted 26 October 2016

Academic Editor: Alexandre Sebbenn

Copyright @ 2016 Markos Kuma. This is an open access article distributed under the Creative Commons Attribution License, which permits unrestricted use, distribution, and reproduction in any medium, provided the original work is properly cited.

\begin{abstract}
This study was conducted in the Community Managed Forests of Gamuwa and Oda of Carbon Project of Humbo, Wolaita, Ethiopia. The objective of the study was to explore diversity of woody species for conservation and management of the forests. A total of 64 $(20 \mathrm{~m} \times 20 \mathrm{~m})$ quadrats were sampled to gather data of species cover abundance, altitude, aspect, and slope. Vegetation clustering was performed from cover abundance using XLSTAT version 2015.2.03 software package. Similarity coefficient was computed using number of species that existed in each community and had been common to them. Diversity indices were computed from number of individuals of each species using Multivariate Variate Statistical Package (MVSP) version 3.1. The General Linear Model (GLM) analysis confirmed the presence of significant difference $(~ p$ value $=0.001)$ of species distribution, altitude, and slope among the quadrates of the three community types. However, except aspect in community 3 ( $p$ value $=0.005$ ) slope, aspect, land cover, and altitude insignificantly affected the distribution of species in communities. Therefore, a priori management and conservation should be given for families with only one species, community with high dominance $\left(D^{\prime}\right)$, and the area with less land cover.
\end{abstract}

\section{Introduction}

Background and Justification. The management of forest ecosystems can pay dividends in terms of water and nutrient availability and reversal of land degradation, having positive impacts on livelihoods and helping in poverty reduction [1, 2]. However, deforestation leads to degradation of the forest and is estimated to contribute globally to a further emission of around $0.5 \mathrm{Gt}$ carbons per year into the atmosphere [3]. A pressure on forestlands of Ethiopia is due to rapid growth of human population $[4,5]$. The anthropogenic activities will influence the vegetation dynamics and tree density at the local and regional scales [6], structure the plant communities of the area [7], determine the size class distribution of species [8], and lead to depletion of forest resources [9].

Botanical assessments are crucial in identifying plant diversity, protecting threatened and economic species, monitoring the status of reserves, and understanding the extent of plant diversity in forest ecosystems [10-12]. Hence, the vegetation analysis enables us to build a mental picture of an area under investigation, compare and ultimately classify communities of the vegetation [13], and understand the relationship that exists within communities and among their environments [14].

Even though the floristic composition, vegetation structure, and regeneration status of woody plant species of Oda forest have been studied [15], the requirement of diversity of woody plant species is not undertaken in the forests. Therefore this study was conducted to identify plant communities and analyze diversity of woody plant species in the forests. In addition to analysis of floristic composition and structure, such a kind of study is fundamental and crucial element for conservation and management of the forests.

\section{Materials and Methods}

2.1. Description of the Study Area. The study areas are located in SNNPR, Wolaita Zone, Humbo Woreda, Hobicha Bongota, and Bolla Wanche Kebeles. The sites are located about 410 to $430 \mathrm{~km}$ away from Addis Ababa (Figure 1). The vegetation of 


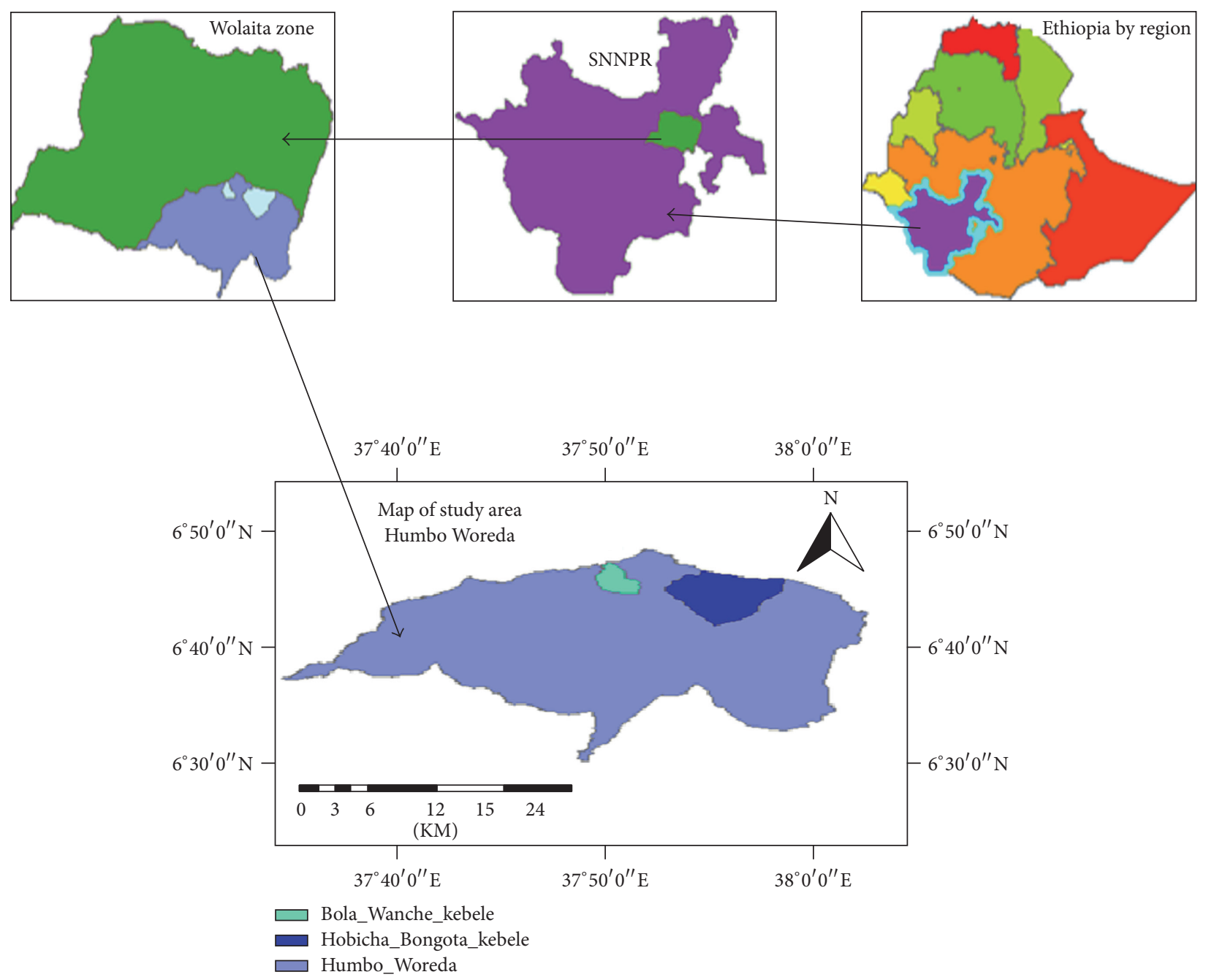

FIGURE 1: Map of study area (source: [15]).

Gamuwa which is found in Bolla Wanche Kebele is positioned at latitude of $6^{\circ} 46^{\prime}$ and $6^{\circ} 45^{\prime} \mathrm{N}$, longitude of $37^{\circ} 49^{\prime}$ and $37^{\circ} 50^{\prime} \mathrm{E}$, and altitude ranges from 1708 to $1882 \mathrm{~m}$ a.s.l.

The vegetation of Oda which is found in Bongota Kebele is situated at latitude of $6^{\circ} 44^{\prime}$, longitude of $37^{\circ} 52^{\prime}$ and $37^{\circ} 53^{\prime} \mathrm{E}$, and altitude ranges from 1625 to $1929 \mathrm{~m}$ a.s.l. [15]. The Oda forest lies within the lowland agroecological zone but Gamuwa forest lies within midland agroecological zone [16].

2.2. Data Collection. The height of individuals of a species, land cover, and cover abundance of woody plant species were collected from each quadrate $(20 \mathrm{~m} \times 20 \mathrm{~m})$. Altitude and coordinate points (using Magellan GPS 315 2001), slope degree (using Suunto Finland clinometers), and aspect (using Silver Type 2 compass) were measured for each quadrat.

The cover abundance data estimated from each quadrat was later converted into cover abundance values using modified 1-9 Braun-Blanquette scale [17]: $1=$ rare (1-3 individuals), $2=$ few individuals, $\leq 5 \%, 3=$ abundant, $\leq 5 \%, 4=$ very abundant, $\leq 5 \%, 5=5-12.5 \%, 6=12.6-25 \%, 7=25.1-50 \%, 8=$ $50.1-75 \%$, and $9=>75 \%$ cover.

\subsection{Data Analysis}

2.3.1. Vegetation Data Analysis. The information recorded from all tree, shrub, and liana species from 64 quadrats was used for identification of plant community and for computation of diversity indices. Plant communities were identified by hierarchical cluster analysis (HCA) using XLSTAT version 2015 based on the cover abundance data of a species in a given quadrat.

Naming of plant communities was carried out after identification of two or three species with the highest mean cover abundance value in each cluster. Individuals having $\mathrm{DBH}$ $<2.5 \mathrm{~cm}$ and height $\leq 0.6 \mathrm{~m}$ were counted as seedling whereas individuals with $2.5 \mathrm{~cm} \leq \mathrm{DBH} \leq 15 \mathrm{~cm}$ and $0.61 \leq$ height $\leq$ $3 \mathrm{~m}$ were counted as sapling [15].

2.3.2. Plant Diversity Analysis. Each community type was identified using mean cover abundance value of the species 
and the diversity of each cluster was calculated by ShannonWeiner diversity index using the following formula:

$$
H^{\prime}=-\sum_{i=1}^{s} P i \ln P i,
$$

where $H^{\prime}$ is diversity of species; $s=$ the number of species; $P i$ $=$ the proportion of individuals abundance of the $i$ th species; and $\ln$ is $\log$ base $_{e}$.

Simpson index $(D)$ and the evenness index ( $J=$ evenness $)$ are used as a measure of species dominance and a measure for evenness of spread of species, respectively [18]:

$$
D=\sum P i^{2}
$$

where $D$ is Simpson index, $P i$ is the proportion of individuals abundance of the $i$ th species, and $\sum$ is summation.

As biodiversity increases, the Simpson index decreases. Therefore, compute $D^{\prime}$ to get a clear picture of species dominance of the community. $D^{\prime}=1-D$.

The even spread of species in the community was calculated by the formula

$$
J=\frac{H^{\prime}}{H \max }=\frac{-\sum_{i=1}^{s} P i \ln P i}{\ln s},
$$

where $J$ is evenness of spread, $H^{\prime}$ is Shannon-Wiener diversity index, $s$ is the number of species, $\ln$ is $\log$ base $_{e}, H$ max is $\ln s$.

Floristic similarities among different quadrates and plant communities were calculated by employing Sörensen's similarity coefficient [19] by using the following equation:

$$
S s=\frac{2 a}{(2 a+b+c)}
$$

where Ss is Sörensen's similarity coefficient, $a$ is number of species common to both samples, $b$ is number of species in sample 1 , and $c$ is number of species in sample 2 .

2.3.3. Environmental Data Analysis. Physiogeographical variables in accordance with the community type identified were computed using SPSS 20 version for their significant effect on species distribution among the plant communities of the forests.

\section{Results}

3.1. Families of the Forests. A total of 80 woody species belonging to 43 families were identified from the forests. Among the families of the area, 1 family of the forests (Fabaceae) was found to be the most dominant family and contributed 10 species to the forests (12.5\%). Twenty-six families of the forests (Acanthaceae, Aloaceae, Anacardiaceae, Annonaceae, Apiaceae, Araliaceae, Bignoniaceae, Dracaenaceae, Ebenaceae, Ericaceae, Flacourtiaceae, Guttiferae, Hypericaceae, Lamiaceae, Melianthaceae, Olacaceae, Oliniaceae, Podocarpaceae, Rubiacea, Santalaceae, Solanaceae, Thymelaeaceae, Ulmaceae, Verbenaceae, and Vitaceae) were found to be the least dominant families and each of them contributed only one species to the forests (32.5\%). But the remaining 16 families (Combretaceae, Oleaceae, Capparidaceae, Celastraceae, Euphorbiaceae, Moraceae, Myrtaceae, Rubiaceae, Sapindaceae, Tiliaceae, Apocynaceae, Asteraceae, Myrsinaceae, Proteaceae, Rhamnaceae, and Rutaceae) contributed 44 species to the forests (55\%). Generally, the families of the forests contributed $45 \%$ of tree species, $52.5 \%$ of shrub species, and $2.5 \%$ of liana species.

3.2. Plant Community Types. Agglomerative hierarchical clustering (AHC) analysis identified three plant communities from the forests using cover abundance data. Twenty-nine quadrats were clustered in community type one, 15 quadrates were clustered in community type two, and 20 quadrats were clustered in community type three of the forests (Figure 2).

3.2.1. Community 1: Syzygium guineense and Dodonaea angustifolia. Twenty-nine quadrats with 76 species clustered in this community type were distributed at average altitude of $1840 \mathrm{~m}$ a.s.l. and slope degree of 18. High mean cover abundance of this community was occupied by Syzygium guineense (7.24), Dodonaea angustifolia (6.03), Combretum molle (3.66), Terminalia schimperiana (3.48), Carissa edulis (3.21), and Euclea schimperi (3.17).

The zero mean cover abundance was occupied by Ocimum gratissimum, Pappea capensis, Piliostigma thonningii, Rytigynia neglecta, and Ximenia americana (Table 1). That means $5 \%$ of the species of the forest were not confined in this community.

3.2.2. Community 2: Euclea schimperi and Dodonaea angustifolia. Fifteen quadrats with 59 species clustered in this community were distributed at the average altitude of $1843 \mathrm{~m}$ a.s.l. and slope of 19. In this community Euclea schimperi (8.27), Dodonaea angustifolia (5.93), Combretum molle (4.8), Rhus natalensis (3.47), Terminalia schimperiana (3.2), and Olea europaea (3.0) were woody species with high mean cover abundance.

The species with zero mean cover abundance were Capparis fascicularis, Ficus vasta, Piliostigma thonningii, Senna petersiana, Garcinia buchananii, Ocimum gratissimum, Acacia senegal, Bersama abyssinica, Polyscias fulva, Gardenia ternifolia, Vernonia filigera, Podocarpus falcatus, Ficus sur, Eucalyptus camaldulensis, Aloe gilbertii, Maesa lanceolata, Erica arborea, Grevillea robusta, Lippia adoensis, Triumfetta brachyceras, and Ziziphus mauritiana (Table 1). That means $26 \%$ of the woody species of the forests were not found in this community.

3.2.3. Community 3: Combretum molle and Dodonaea angustifolia. Twenty quadrates with 61 species clustered in this community were distributed at average altitude of $1732 \mathrm{~m}$ a.s.l. and slope of 22. The species with high mean cover abundance in this community were Combretum molle (6.55), Dodonaea angustifolia (5.8), Rhus natalensis (5.1), Combretum collinum (4.3), and Schrebera alata (3.7).

The woody species with zero mean cover abundance in this community were Aloe gilbertii, Combretum aculeatum, 
TABLE 1: Mean cover abundance of Woody species.

\begin{tabular}{|c|c|c|c|}
\hline Community type & 1 & 2 & 3 \\
\hline Number of quadrats & 29 & 15 & 20 \\
\hline Combretum molle R.Br. ex G. & 3.66 & 4.8 & 6.55 \\
\hline Dodonaea angustifolia L.f. & 6.03 & 5.93 & 5.8 \\
\hline Rhus natalensis Bernh. ex Krauss & 0.55 & 3.47 & 5.1 \\
\hline Combretum collinum Fresen. spp. binderianum (Kotschy) Okofor & 1.1 & 1.4 & 4.3 \\
\hline Schrebera alata (Hochst.) Welw. & 1.62 & 2.6 & 3.7 \\
\hline Terminalia schimperiana Hochst. & 3.48 & 3.2 & 1.95 \\
\hline Calpurnia aurea (Ait.) Benth. & 0.86 & 2.33 & 1.9 \\
\hline Olea capensis L. & 1.86 & 1.93 & 1.75 \\
\hline Acacia hockii De Wild. & 0.21 & 0.67 & 1.6 \\
\hline Dichrostachys cinerea L. & 2.41 & 0.8 & 1.5 \\
\hline Clutia abyssinica Jaub. \& Spach & 0.72 & 0.4 & 1.4 \\
\hline Carissa edulis L. & 3.21 & 2.73 & 1.2 \\
\hline Allophylus abyssinicus (Hochst.) Radlk. & 1.55 & 1.93 & 1.2 \\
\hline Grewia bicolor Juss. & 0.14 & 0.47 & 1.15 \\
\hline Pterolobium stellatum (Forssk.) Brenan & 0.17 & 1 & 0.95 \\
\hline Albizia schimperiana Oliv. & 0.14 & 0.53 & 0.85 \\
\hline Jasminum floribundum R.Br. ex Fresen. & 0.79 & 0.8 & 0.8 \\
\hline Ozoroa pulcherrima (Schweinf.) R. \& A. Fernandes & 0.1 & 0.4 & 0.75 \\
\hline Euclea schimperi (A.DC.) Dandy & 3.17 & 8.27 & 0.6 \\
\hline Myrtus communis $\mathrm{L}$. & 1.03 & 1.8 & 0.6 \\
\hline Maerua oblongifolia (Forsk.) A. Rich. & 0.24 & 0.13 & 0.6 \\
\hline Croton macrostachyus Hochst. & 0.41 & 0.8 & 0.55 \\
\hline Rhoicissus revoilii Planch. & 0.41 & 0.47 & 0.55 \\
\hline Markhamia lutea (Benth.) K.Schum. & 0.72 & 0.87 & 0.5 \\
\hline Acokanthera schimperi (A.DC.) Schweinf. & 0.9 & 2 & 0.45 \\
\hline Olea europaea L. ssp. cuspidata (Wall. ex G. Don) Cif. & 1.69 & 3 & 0.4 \\
\hline Hypericum revolutum Vahl & 2.14 & 1.2 & 0.4 \\
\hline Teclea nobilis Del. & 0.21 & 0.07 & 0.4 \\
\hline Maytenus gracilipes (Welw. ex Oliv.) Exell & 0.86 & 0.73 & 0.35 \\
\hline Vernonia karaguensis Oliv. \& Hiern. & 0.1 & 0.33 & 0.35 \\
\hline Flacourtia indica (Burm.f.) Merr. & 0.21 & 0.2 & 0.35 \\
\hline Olinia rochetiana A. Juss. & 1.34 & 2.07 & 0.3 \\
\hline Grewia velutina (Forssk.) Vahl & 0.03 & 0.07 & 0.3 \\
\hline Capparis fascicularis DC. & 0.07 & 0 & 0.3 \\
\hline Syzygium guineense (Willd.) DC. & 7.24 & 0.93 & 0.25 \\
\hline Protea gaguedi J. F. Gmel. & 1.34 & 0.8 & 0.25 \\
\hline Entada abyssinica Steud. ex A. Rich. & 0.24 & 0.27 & 0.25 \\
\hline Ficus vasta Forssk. & 0.03 & 0 & 0.25 \\
\hline Clutia lanceolata Forssk. & 0.52 & 0.53 & 0.2 \\
\hline Maerua angolensis DC. & 0.55 & 0.4 & 0.2 \\
\hline Osyris quadripartita Decn. & 0.34 & 0.33 & 0.2 \\
\hline Piliostigma thonningii (Schumach.) Milne-Rodh. & 0 & 0 & 0.2 \\
\hline Fagaropsis angolensis (Engl.) Milne-Redh. & 0.07 & 0.27 & 0.15 \\
\hline Senna petersiana (Bolle) Lock & 0.07 & 0 & 0.15 \\
\hline Rothmannia urcelliformis (Hiern) Robyns & 0.66 & 0.87 & 0.1 \\
\hline Rhamnus prinoides L. Herit & 0.34 & 0.4 & 0.1 \\
\hline Gnidia glauca (Fresen.) Gilg. & 0.17 & 0.4 & 0.1 \\
\hline Maytenus senegalensis (Lam.) Exell & 0.41 & 0.27 & 0.1 \\
\hline Sansevieria ehrenbergii Schweinfurt ex Baker & 0.14 & 0.2 & 0.1 \\
\hline Crotalaria pallida L. & 0.14 & 0.13 & 0.1 \\
\hline
\end{tabular}


TABLE 1: Continued.

\begin{tabular}{|c|c|c|c|}
\hline Community type & 1 & 2 & 3 \\
\hline Number of quadrats & 29 & 15 & 20 \\
\hline Garcinia buchananii Baker. & 0.24 & 0 & 0.1 \\
\hline Ocimum gratissimum $\mathrm{L}$. & 0 & 0 & 0.1 \\
\hline Uvaria scheffleri Diels & 1.41 & 1.4 & 0.05 \\
\hline Ficus ingens $\mathrm{L}$. & 0.03 & 0.73 & 0.05 \\
\hline Salacia congolensis De Wild. \& Th. Dur. & 0.28 & 0.33 & 0.05 \\
\hline Celtis africana Burm.f. & 0.24 & 0.07 & 0.05 \\
\hline Acacia senegal (L.) Willd. & 0.38 & 0 & 0.05 \\
\hline Bersama abyssinica Fresen. & 0.1 & 0 & 0.05 \\
\hline Polyscias fulva (Hiern) Harms & 0.07 & 0 & 0.05 \\
\hline Gardenia ternifolia Schumach. & 0.03 & 0 & 0.05 \\
\hline Vernonia filigera Oliv. \& Hiern. & 0.03 & 0 & 0.05 \\
\hline Pappea capensis Eckl. \& Zeyh. & 0 & 0.27 & 0 \\
\hline Combretum aculeatum Vent & 0.41 & 0.2 & 0 \\
\hline Tricalysia niamniamensis Heirn & 0.31 & 0.13 & 0 \\
\hline Justicia adhatoda L. & 0.07 & 0.13 & 0 \\
\hline Ximenia Americana L. & 0 & 0.13 & 0 \\
\hline Myrsine africana $\mathrm{L}$. & 0.45 & 0.07 & 0 \\
\hline Steganotaenia araliacea Hochst. ex A. Rich & 0.1 & 0.07 & 0 \\
\hline Solanum incanum L. & 0.03 & 0.07 & 0 \\
\hline Rytigynia neglecta (Hiern) Robyns & 0 & 0.07 & 0 \\
\hline Podocarpus falcatus (Thunb.) & 0.21 & 0 & 0 \\
\hline Ficus sur Forsk & 0.17 & 0 & 0 \\
\hline Eucalyptus camaldulensis Dehnh. & 0.1 & 0 & 0 \\
\hline Aloe gilbertii Sebsebe \& Brandham & 0.07 & 0 & 0 \\
\hline Maesa lanceolata Forssk. & 0.07 & 0 & 0 \\
\hline Erica arborea $\mathrm{L}$. & 0.03 & 0 & 0 \\
\hline Grevillea robusta $\mathrm{R} . \mathrm{Br}$. & 0.03 & 0 & 0 \\
\hline Lippia adoensis Hochst. ex Walp. & 0.03 & 0 & 0 \\
\hline Triumfetta brachyceras K. Schum. & 0.03 & 0 & 0 \\
\hline Ziziphus mauritiana Lam. & 0.03 & 0 & 0 \\
\hline
\end{tabular}

Erica arborea, Eucalyptus camaldulensis, Ficus sur, Grevillea robusta, Justicia adhatoda, Lippia adoensis, Maesa lanceolata, Myrsine africana, Pappea capensis, Podocarpus falcatus, Rytigynia neglecta, Solanum incanum, Steganotaenia araliacea, Tricalysia niamniamensis, Triumfetta brachyceras, Ximenia americana, and Ziziphus mauritiana (Table 1). That means $23.8 \%$ of the woody species of the forests were not found in this community.

3.3. Community Diversity. In the forests of the study area, community 1 was the most diverse and species-rich community followed by communities 3 and 2, respectively. But the dominance $\left(D^{\prime}\right)$ of species in the communities was decreased even though diversity of species among the communities increases. On the other hand, evenness and richness of species were increased with the decrease of dominance $\left(D^{\prime}\right)$ among the communities (Table 2). Besides, the Univariate Analysis (UVA) on Shannon's index $\left(H^{\prime}\right)$, dominance $\left(D^{\prime}\right)$, evenness $(J)$, and richness showed significant variation of diversity $(p<0.01)$, difference of dominance of species $(p<0.01)$, disparity of equitable species distribution $(p<$ $0.01)$, and variation of species richness $(p<0.05)$ among the communities of the forests.

3.4. Similarities of Communities in the Forests. Sörensen's similarity coefficient computed for the floristics of the communities indicated the difference of floristics in communities 1 and 2, 1 and 3, and 2 and 3. Besides, Sörensen's similarity coefficient computed for the floristics of the communities indicated the existence of least similarity of floristics in communities 1 and 3, as well as 2 and 3 (Table 3).

The Univariate Analysis (UVA) on Sörensen's similarity coefficient computed among the communities confirmed the presence of significant difference of similarities $(p<0.01)$ of communities of the forests. Hence, UVA on number of species in each community indicated the presence of significant difference in floristics $(p<0.05)$ among communities of the forest.

The General Linear Model (GLM) analysis confirmed the presence of significant difference $(p<0.01)$ of species 
TABLE 2: Diversity of species in communities of the forests.

\begin{tabular}{lccccc}
\hline Community type & Shannon's Index $\left(H^{\prime}\right)$ & Simpson's index $(D)$ & Dominance $\left(D^{\prime}\right)$ & Evenness $(J)$ & Richness \\
\hline 1 & 2.951 & 0.892 & 0.108 & 0.904 & 75 \\
2 & 2.855 & 0.882 & 0.118 & 0.897 & 60 \\
3 & 2.905 & 0.888 & 0.112 & 0.903 & 61 \\
\hline
\end{tabular}

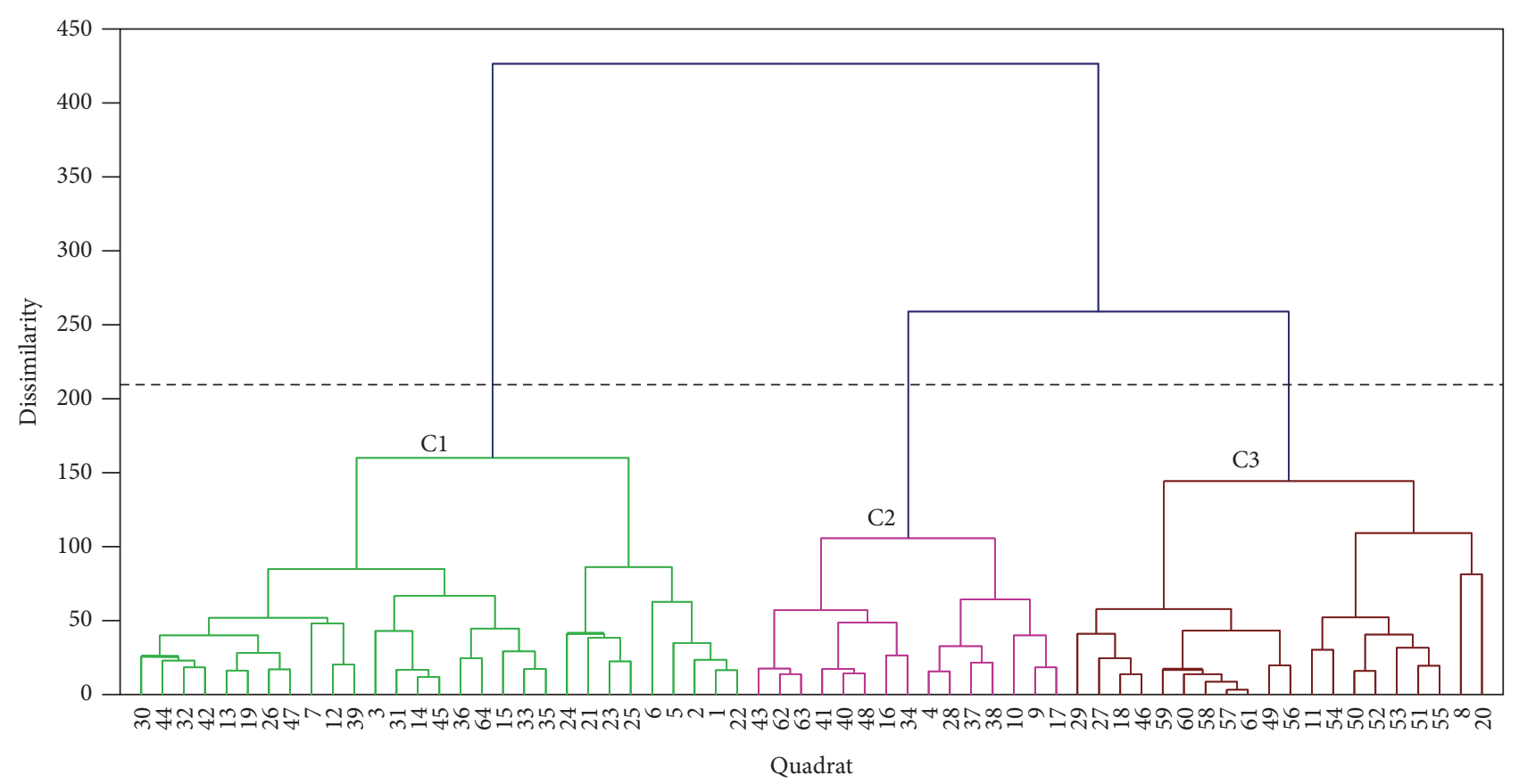

FIGURE 2: Dendrogram that shows community type of the forests (green $=\mathrm{C} 1$, pink $=\mathrm{C} 2$, and red $=\mathrm{C} 3=$ community type). Note: in the dendrogram a broken line marks that the level of truncation has been carried out and the dissimilarity level of the community.

TABLE 3: Sörensen's similarity of communities of study areas.

\begin{tabular}{lcc}
\hline Community & Sörensen's similarity & $p$ value \\
\hline $\mathrm{C} 1$ and C2 & 0.45 & \\
$\mathrm{C} 1$ and C3 & 0.47 & 0.0001 \\
$\mathrm{C} 2$ and C3 & 0.48 & \\
\hline
\end{tabular}

distribution, altitude, and slope among the quadrates of the three community types. However, except aspect in community $3(p<0.05)$ slope, aspect, land cover, and altitude insignificantly affected the distribution of species in communities 1,2 , and 3 .

\section{Discussion}

Among 43 families identified, Fabaceae was the most dominant family of the forests which is similarly reported by Kuma and Shibru [15] from Oda forest. In the forests, 35\% of the families had only one species for each. These families, with only one species, are susceptible to extinction either due to anthropogenic activities or due to unsuitable environmental conditions or due to both. Therefore, sound conservation and management must be given for species susceptible to extinction in in situ conditions.
In the forests, three main community types were identified. The community with large number of quadrats clustered together had highest number of species compared to that of less number of quadrats clustered together. In other words, the species richness or diversity of species was high in the community with large number of quadrats clustered together compared to the community with less number of quadrats clustered together. That means evenness and richness were increased with the increase of number of quadrats clustered in the communities of the forests. Therefore special consideration on conservation as well as management of the forests must be given for community with less number of species and for the community with less dominance $\left(D^{\prime}\right)$ and high Shannon's index $\left(H^{\prime}\right)$ value.

The General Linear Model (GLM) confirmed the presence of significant difference $(p$ value $=0.001)$ of species distribution, altitude, and slope among the quadrates of the three community types. However, except aspect in community 3 ( $p$ value $=0.005$ ) slope, aspect, land cover, and altitude insignificantly affected the distribution of species in communities 1 , 2, and 3. But study on separate forest (Oda only) by Kuma and Shibru [15] confirmed the presence of significant effect of altitude and slope on species distribution in the forest. This confirmed that studies on separate forest had clear indication for the environmental and climatic factors that affect the 
distribution of species in the communities as well as in the forest compared to that of the merged one.

Even though the forests were under protection, in support with Gurmu [16] and Ramírez-Marcial et al. [9] studies, there were major anthropogenic activities carried out in the study sites. Some of the activities seriously observed in the areas were cattle overgrazing, cutting of trees for fire wood, charcoal production and house construction, harvesting of grasses for roof cover, and setting of fire near the forest by owners adjacent to the forests to expand their land and protect crops from monkey.

In the forests mowing of grasses decrease the seeds return into seed bank by taking away from the forest; firing the forests reduces dormancy period of the seeds by damaging seed coats; and cutting of trees and grazing reduce production of seeds by reducing twigs and flower development. In support with Sumina [7], Hubbell et al. [6], Luoga et al. [8], Kennard et al. [20], and Sapkota et al. [21] the disturbances from anthropogenic activities influence the vegetation dynamics, agitate tree density at the local and regional scales, determine the size class distribution of species, important in structuring plant communities, influence species diversity in the forest community, and alter environmental conditions.

As it has been realized from the neutral informants, rising of the above factors was due to lack of knowledge and awareness and misunderstanding and dislike of enclosure of forests for conservation and management in the carbon project. Misunderstanding of the people at the vicinity was due to the consideration that the forests decline their economy by producing more destructive wild animals like hyena, leopard, and monkey.

However, the forests are sprouting different medicinal plants like Maytenus senegalensis which is used for alleviating snake bites and Maerua oblongifolia used for killing stomach worms. Besides, the forests are reducing soil erosion, generating income, increasing agricultural productivity, and stabilizing climate change in harmony with the idea of Bruijnzeel [22], Enters [23], and Wilkie and Trexler [24].

\section{Conclusion and Recommendations}

5.1. Conclusion. Three communities were identified in the forests of Gamuwa and Oda. Among the families, only 16 families $(37.2 \%)$ had more than one species but $60.5 \%$ of the families (26) of the forests had only one species each. The families with one species only are susceptible to extinction either due to anthropogenic activities or due to unsuitable environmental conditions or due to both and need special management and in situ conservation.

In the forests $5 \%$ from community $1,26 \%$ from community $2,23.8 \%$ from community 3 of the species had zero mean cover abundance. That means the proportion of an area in a quadrat covered by every species was best in community 1 , better in community 3 , and good in community 2 . In other words, the number of zero cover abundance instances indicates species richness of the community and it is inversely proportional to species richness of the community. Therefore communities with high percent of zero cover abundance should be given priority in conservation and management of the forest.

The distribution of species among the communities of the forests is insignificantly affected by average altitude and slope ( $p$ value $=0.199)$. But separate study carried out on Oda forest confirmed the significant effect of altitude and slope on the woody plant species distribution in the forest. This indicated that environmental factors study with respect to species distribution among the communities should be done in each forest to have clear image of influence of each environmental factors.

\subsection{Recommendations}

(i) As it has been newly established project on almost totally cleared off area with an aim of decreasing carbon emission, the concerned bodies should make great effort to dig out the problems and find out solutions on the burning issues of the environment.

(ii) Detailed socioeconomic importance and ecological studies are required for conservation and management of the forests.

(iii) Sustainable management and conservation efforts should be made through collaboration of the government, NGO, and local community to reduce carbon emission, to stabilize weather conditions, and to have effective ecosystem services.

\section{Competing Interests}

Markos Kuma declares that there is no conflict of interests regarding the publication of this article.

\section{Acknowledgments}

The author is grateful to Wolaita Sodo University for providing the fund for the activities that have been carried out in this research.

\section{References}

[1] R. Lal, "Soil science and the carbon civilization," Soil Science Society of America Journal, vol. 71, no. 5, pp. 1425-1437, 2007.

[2] P. Smith, D. Martino, Z. Cai et al., "Agriculture," in Climate Change 2007: Mitigation. Contribution of Working Group III to the Fourth Assessment Report of the Intergovernmental Panel on Climate Change, B. Metz, O. R. Davidson, P. R. Bosch, R. Dave, and L. A. Meyer, Eds., pp. 497-540, Cambridge University Press, Cambridge, UK, 2007.

[3] F. Achard, H. D. Eva, P. Mayaux, H.-J. Stibig, and A. Belward, "Improved estimates of net carbon emissions from land cover change in the tropics for the 1990s," Global Biogeochemical Cycles, vol. 18, no. 2, p. GB2008, 2004.

[4] FDRE (Federal Democratic Republic of Ethiopia), Ethiopia's Climate-Resilient Green Economy, Green Economy Strategy, Addis Ababa, Ethiopia, September 2011.

[5] World Bank, World Development Indicators (WDI), 2012. 
[6] S. P. Hubbell, R. B. Foster, S. T. O’Brien et al., "Light-gap disturbances, recruitment limitation, and tree diversity in a neotropical forest," Science, vol. 283, no. 5401, pp. 554-557, 1999.

[7] O. I. Sumina, "Plant communities on Anthrop genetically disturbed sited on the Chukotkapensula, Russia," Journal of Vegetation Science, vol. 5, pp. 885-896, 1994.

[8] E. J. Luoga, E. T. F. Witkowski, and K. Balkwill, "Regeneration by coppicing (resprouting) of miombo (African savanna) trees in relation to land use," Forest Ecology and Management, vol. 189, no. 1-3, pp. 23-35, 2004.

[9] N. Ramírez-Marcial, M. González-Espinosa, and G. WilliamsLinera, "Anthropogenic disturbance and tree diversity in Montane Rain Forests in Chiapas, Mexico," Forest Ecology and Management, vol. 154, no. 1-2, pp. 311-326, 2001.

[10] D. Tilman, Plant Strategies and the Dynamics and Structure of Plant Communities, Princeton University Press, Princeton, NJ, USA, 1988.

[11] WCMC, World Conservation Monitoring. Global Biodiversity: Status of Earth's Living Resources Dhagman and Hall, WCMC, London, UK, 1992.

[12] P. Ssegawa and D. N. Nkuutu, "Diversity of vascular plants on Ssese islands in Lake Victoria, central Uganda," African Journal of Ecology, vol. 44, no. 1, pp. 22-29, 2006.

[13] K. A. Kershaw, Quantitative and Dynamic Plant Ecology, Edward Arnold Publishers LTD, London, UK, 2nd edition, 1973.

[14] D. W. Shimwell, The Description and Classification of Vegetation, University of Washington Press, Seattle, Wash, USA, 1984.

[15] M. Kuma and S. Shibru, "Floristic composition, vegetation structure, and regeneration status of woody plant species of oda forest of Humbo Carbon Project, Wolaita, Ethiopia," Journal of Botany, vol. 2015, Article ID 963816, 9 pages, 2015.

[16] D. Gurmu, "Humbo community-managed natural regeneration project," Final report, 2006.

[17] E. Van der Maabel, "Transformation of cover-abundance values in phytosociology and its effects on community similarity," Vegetatio, vol. 39, no. 2, pp. 97-114, 1979.

[18] A. E. Magurran, Ecological Diversity and Measurement, Princeton University Press, Princeton, NJ, USA, 1988.

[19] M. Kent and P. Coker, Vegetation Description and Analysis. A Practical Approach, Belhaven Press, London, UK, 1992.

[20] D. K. Kennard, K. Gould, F. E. Putz, T. S. Fredericksen, and F. Morales, "Effect of disturbance intensity on regeneration mechanisms in a tropical dry forest," Forest Ecology and Management, vol. 162, no. 2-3, pp. 197-208, 2002.

[21] A. Sapkota, A. P. Chelikowsky, K. E. Nachman, A. J. Cohen, and B. Ritz, "Exposure to particulate matter and adverse birth outcomes: a comprehensive review and meta-analysis," Air Quality, Atmosphere \& Health, vol. 5, no. 4, pp. 369-381, 2012.

[22] L. A. Bruijnzeel, Hydrology of Moist Tropical Forests and Effects of Conversion: A State of Knowledge Review, Humid Tropics Programme, IHP-UNESCO, Paris, France; Vrije Universiteit, Amsterdam, The Netherlands, 1990.

[23] T. Enters, Land degradation and resource conservation in the highlands of northern Tailand: the limits to economic evaluations [Ph.D. thesis], Australian National University, Canberra, Australia, 1992.

[24] S. D. Wilkie and M. C. Trexler, "Bio geophysical setting and global climate change," Central Africa: Global Climate Change and Development. Technical Report, Biodiversity Support Program (A Consortium of World Wildlife Fund, The Nature Conservancy, and World Resources Institute), Washington, DC, USA, 1993. 

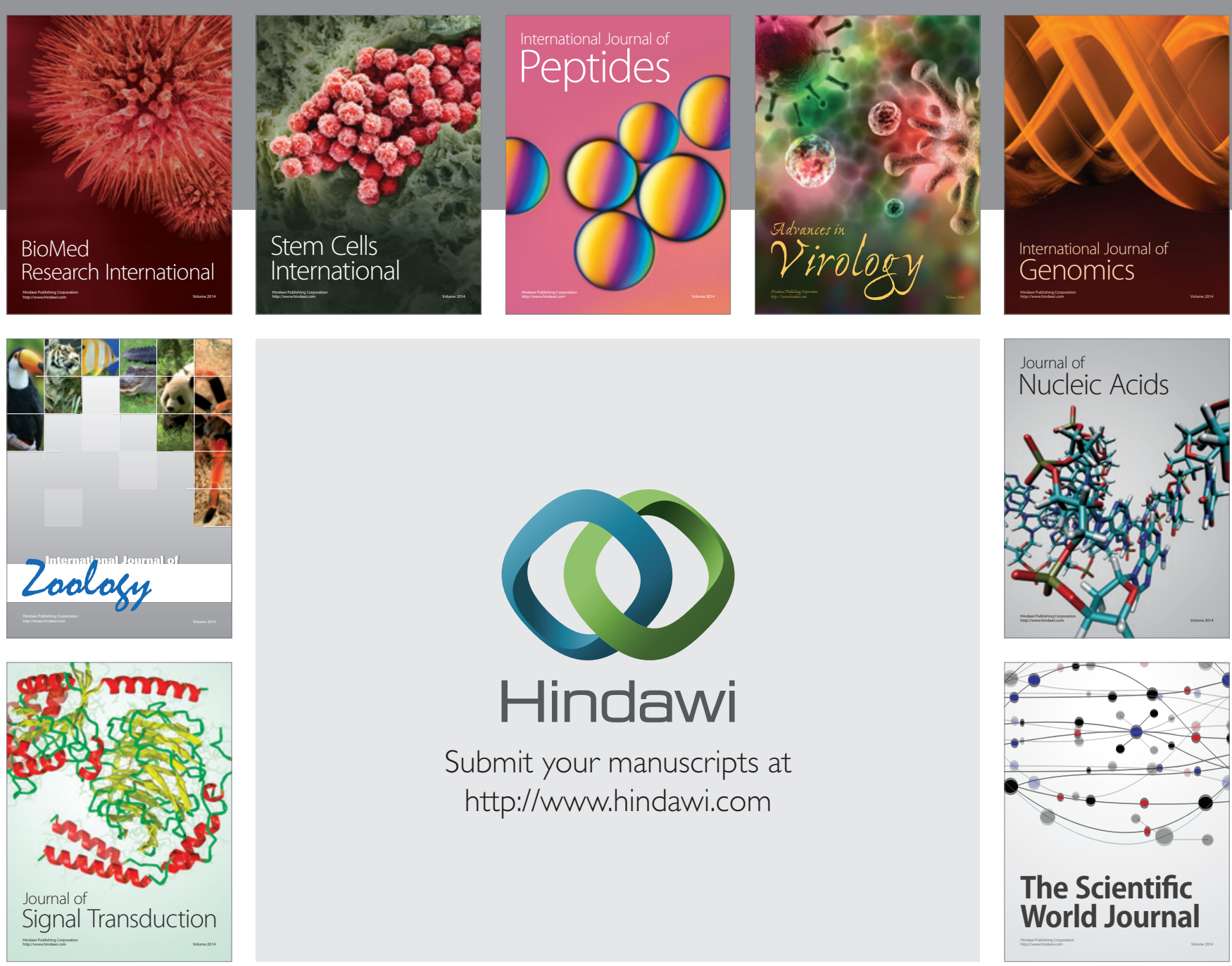

Submit your manuscripts at

http://www.hindawi.com
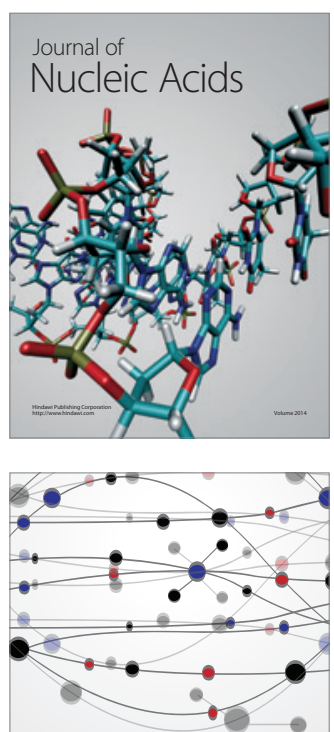

The Scientific World Journal
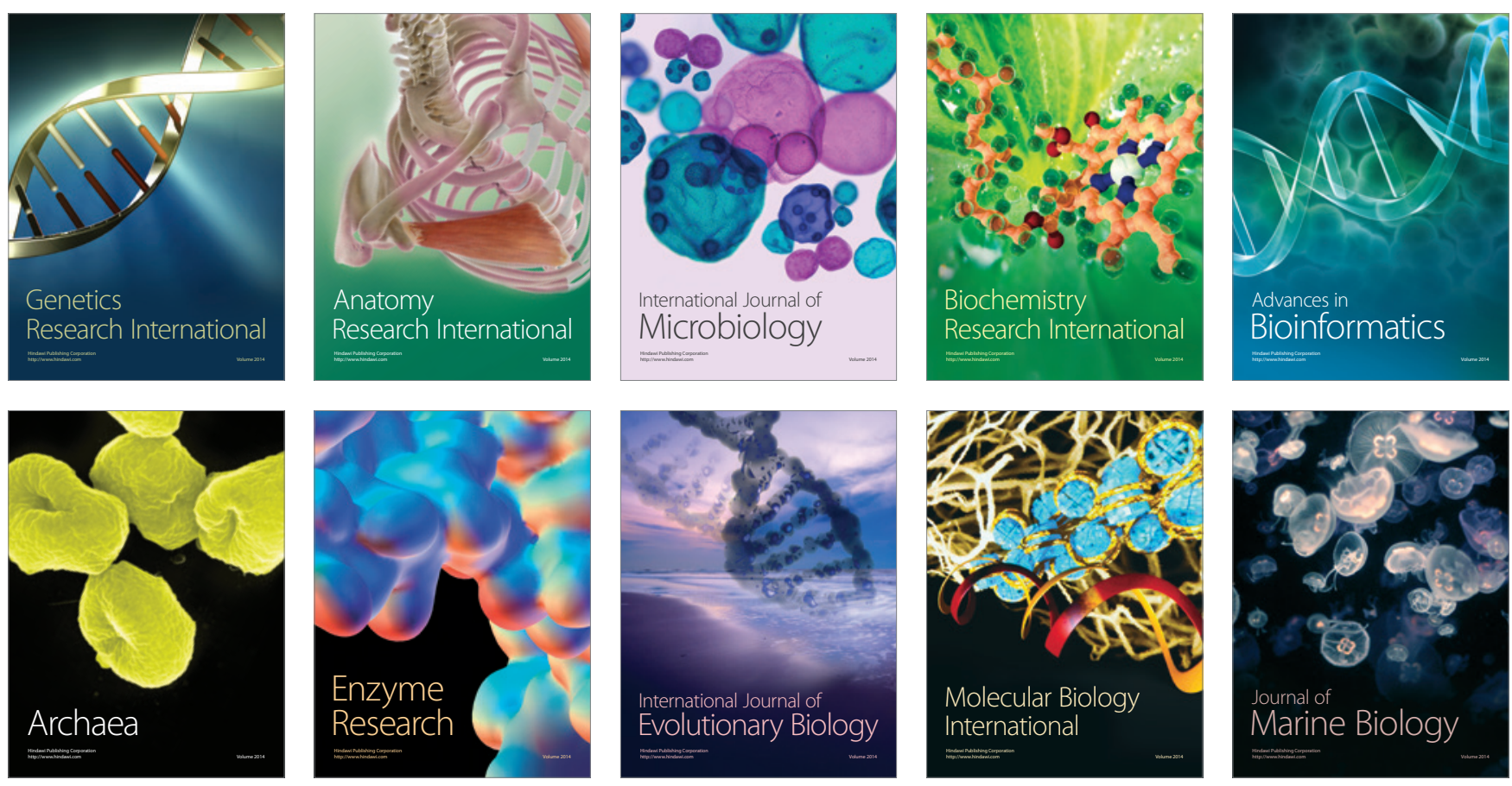